Racial TRANSFORMATIONS 



\section{Racial TRANSFORMATIONS}

Latinos and Asians

Remaking the United States

Edited by Nicholas De Genova

Duke University Press

Durham and London 2006 
(C) 2006 Duke University Press

All rights reserved

Printed in the United States of America on acid-free paper $\infty$

Designed by Heather Hensley

Typeset in Bembo by Keystone

Typesetting, Inc.

Library of Congress Cataloging-in-

Publication Data appear on the last printed page of this book. 